\title{
Association of mesenchymal stem cells with platelet rich plasma on the repair of critical calvarial defects in mice ${ }^{1}$
}

\author{
Associação de células-tronco mesenquimais com plasma rico em plaquetas na reparação de \\ defeitos críticos em calvária de camundongos
}

\author{
Betânia Souza MonteiroI, Ricardo Junqueira Del Carlo" ${ }^{\mathrm{II}}$, Napoleão Martins Argôlo-Neto ${ }^{\mathrm{III}}$, Nance Beyer Nardi ${ }^{\mathrm{IV}}$, Pablo Herthel

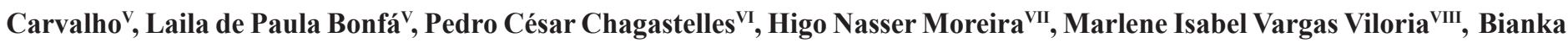 \\ Souza dos Santos ${ }^{\mathrm{IX}}$
}

IPhD, Full Professor, Department of Veterinary, Vila Velha University (UVV), Espirito Santo, Brazil. Main author, surgery and cell culture. "IPhD, Full Professor, Department of Veterinary, UFV, Viçosa-MG, Brazil. Responsible for intellectual, scientific content of the study and critical revision.

IIIPhD, Fellow Pos-PhD degree, Federal University of Piaui (UFPI), Brazil. Cell culture protocols and anesthesia.

${ }^{\text {IV }}$ Pos-DSc, Full Professor, Department of Biology, Lutheran University of Brazil (ULBRA), Porto Alegre-RS, Brazil. Cell culture protocols and critical revision.

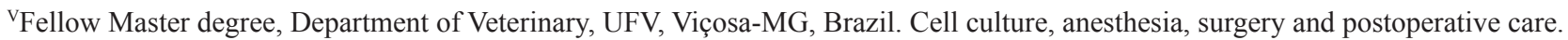

${ }^{\mathrm{VI}} \mathrm{PhD}$, Department of Immunogenetic, Federal University of Rio Grande do Sul (UFRGS), Porto Alegre-RS, Brazil. Cell culture and flow citometry.

VIIFellow Master degree, Department of Molecular Biology, UFV, Viçosa-MG, Brazil. PCR analyses.

VIIIPhD, Associate Professor, Department of Veterinary, UFV, Viçosa-MG, Brazil. Cell culture and histology analyses.

${ }^{\mathrm{IX}}$ Fellow Master degree, Department of Veterinary, UVV, Vila Velha-ES, Brazil. Surgery and postoperative care.

\begin{abstract}
PURPOSE: To evaluate the effects of mesenchymal stem cells (MSC) from eight mice C57BL/6 gfp + bone marrows expanded in cultures associated with platelets rich plasma (PRP) deriving from another eight mice, in the repair of critical defects in calvarial bone produced in twenty-four adult isogenic mice C57BL/6.

METHODS: The animals were submitted to a cranial defect of $6.0 \mathrm{~mm}$ in diameter and divided into two equal experimental groups. Control group did not receive treatment and the treated group received a MSC pellet containing $1.0 \times 10^{7}$ cells $/ \mathrm{mL}$ associated with $50.0 \mu \mathrm{L}$ of plasma gel containing $1.0 \times 10^{9}$ autologous platelets within the defect.

RESULTS: In the treated group was observed process of angiogenesis and bone repair better than control group.

CONCLUSION: Mesenchymal stem cells derived from bone marrow of C57BL/6 $g f p^{+}$mice associated with PRP gel applied in bone critical defects produced in calvarial contributes positively to the process of bone repair.
\end{abstract}

Key words: Mesenchymal Stem Cells. Platelet-Rich Plasma. Tissue Therapy. Skull. Mice.

\section{RESUMO}

OBJETIVO: Avaliar os efeitos da associação das células-tronco mesenquimais (MSC) oriundas da medula óssea de oito camundongos jovens C57BL/6 $g f p^{+}$e expandidas em culturas, com Plasma Rico em Plaquetas (PRP) provenientes de outros oito camundongos, na reparação de defeitos críticos confeccionados em calvária de 24 camundongos adultos C57BL/6.

MÉTODOS: Os animais foram submetidos a um defeito craniano de 6,0mm de diâmetro e separados em dois grupos experimentais iguais. O grupo controle não recebeu tratamento e no grupo tratado foi administrado, no interior do defeito, pellet de MSC contendo 1,0 x $10^{7}$ células/mL associado com $50,0 \mu \mathrm{L}$ de plasma em gel autólogo contendo $1,0 \times 10^{9}$ plaquetas.

RESULTADOS: No grupo tratado verificou-se processo de angiogênese e reparação óssea superior ao grupo controle.

CONCLUSÃO: A associação das células-tronco mesenquimais (MSC) derivadas da medula óssea de camundongos C57BL/6 gfp $p^{+}$com gel de PRP aplicadas em defeitos ósseos críticos confeccionadas em calvária de camundongos C57BL/6 jovens, contribuiu positivamente para o processo de reparação óssea.

Descritores: Células-Tronco Mesenquimais. Plasma Rico em Plaquetas. Terapia Tecidual. Crânio. Camundongos. 


\section{Introduction}

New therapies aimed at tissue repair in regions which are hardship to heal, the bones of the skull and the jaw has used cell therapy osteogenic with osteoinductor growth factors's and vehicles biocompatible ${ }^{1}$. At the context the use of a modern therapeutic arsenal, some research associate mesenchymal stem cells (MSC) with different growth factors, among them, the factors coming from the Platelet Rich Plasma (PRP), important in the induction of bone formation ${ }^{2}$.

MSC are somatic stem cells present in specialized niches in the perivascular regions of adult tissues ${ }^{3,4}$, with the potential to differentiate into multilineage cell, among them, the patients with osteogenic phenotype ${ }^{5,6}$. This cell type is routinely isolated from different tissues, especially bone marrow (BM), and widely expanded through successive mitoses. On cultures, exhibit inherent properties such as fibroblastoid cell shape, adhesion to plastic substrate, ability to self-renewal and ability to differentiate, under appropriate conditions of cultivation in different cell types ${ }^{7}$.

The plasticity coupled with expansion hability, immunomodulatory effects and the possibility to be vector to the therapeutic genes, make this group cellular target of great interest in regenerative medicine ${ }^{8,9}$.

Platelet Rich Plasma (PRP) has been described as a biomaterial accelerator of bone formation that contains blood proteins and many platelet-releasing of different types and amounts of growth factors (GF) with osteoinductive characteristics ${ }^{10,11}$.

The basic mechanisms and interactions of soluble factors released by the plasma with undifferentiated cells from stroma are not well elucidated ${ }^{2}$. In vitro studies have demonstrated that GF released by the plasma are strongly mitogenic for MSC and osteoblast lineage cells ${ }^{12}$. In vivo, have been suggested synergistic effect of the combination of MSC with PRP, resulting in increased bone formation in regions difficult to consolidation, such as maxillofacial and skull ${ }^{1}$.

This present study aimed to evaluate the effects of the association of mesenchymal stem cells (MSC) derived from bone marrow and expanded in cultures, with Platelet Rich Plasma (PRP), in the repair of critical defects of adult isogenic mice C57BL/6.

\section{Methods}

This project was approved by the Ethics Committee on Animal Experiments of Department of Veterinary of Federal University of Viçosa, processed 46/2007, in accordance with the standards of the Brazilian College of Animal Experimentation.
A total of 40 male mice of lineage C57BL/6, average body weight of 30.0 grams, six months old. Eight animals were blood donors to obtain platelet rich plasma (PRP), eight animals were bone marrow donors for the accomplishment of cell culture and the remaining 24 were used for experiments in vivo, were divided into two equals experimental groups.

The animals were housed individually in cages of 0.15 $\mathrm{m}^{2}$, under a photoperiod of 12 hours, with controlled temperature and humidity, minimal noise, solid and fed chow and water ad libitum.

\section{Obtaining the PRP}

Eight animals were anesthetized using isoflurane at a gas chamber, and contained in the supine position. Subsequently, sternal thoracotomy was performed, the left ventricle was punctured with a 25gauge needle, and collected the entire circulating blood volume, approximately $2.0 \mathrm{~mL}$ per animal. The blood was immediately transported to sterile bottle containing sodium citrate and centrifuged for 5 minutes, the speed of $1500 \mathrm{rpm}$. After centrifugation, the plasma was removed and placed in another jar, and again centrifuged for 5 minutes at 1500rpm. With the aid of an adjustable automatic pipette in $100.0 \mu \mathrm{L}$, the superficial phase of the plasma was discarded, leaving only a portion rich in platelets. The total volume of plasma was subjected to counting and distributed in twelve centrifuge tubes, each containing $50.0 \mu \mathrm{L}$ of plasma plus $25.0 \mu \mathrm{L}$ of calcium gluconate $10 \%$, which were placed in a water bath at $37^{\circ} \mathrm{C}$ until freeze protection plasma. After the formation of the PRP gel, the vials were sealed and taken to the operating room. The preparation of plasma happened moments before the application.

\section{Culture of mesenchymal stem cells}

Primary culture cells were collected from bone marrow of adult mice transgenic C57BL/6 for the reporter gene $g f p$ (green fluorescens protein) and deposited in the growth plate with cell culture medium and kept in incubator at $37^{\circ} \mathrm{C}$ in $5 \% \mathrm{CO}_{2}$ and $95 \%$ humidity. When cell growth had averaged $80 \%$ confluent cells was performed trypsinization, counting and replating of these cells in culture flasks of $25.0 \mathrm{~cm}^{2}$.

\section{Expansion of primary culture}

The culture medium was completely removed from the bottle and the bottles were washed with $3.0 \mathrm{~mL}$ of phosphate saline buffering solution (PBS 1x, pH 7.2). Then, the cells adhered to the bottom of the bottle were trypsinized with $0.25 \%$ trypsin solution and incubated at $37^{\circ} \mathrm{C}$ in $5 \% \mathrm{CO}_{2}$ and $95 \%$ humidity 
for 5 minutes. Subsequently, cells were resuspended in $5.0 \mathrm{~mL}$ of complete medium and the suspension containing the MSC was transferred to centrifuge tubes and centrifuged at a temperature of $22^{\circ} \mathrm{C}$ and $1500 \mathrm{rpm}$ for 10 minutes. The supernatant was completely discarded and the pellet was resuspended in centrifuge tubes containing $1.0 \mathrm{~mL}$ of $1 \mathrm{x}$ PBS.

An aliquot of $10.0 \mu \mathrm{L}$ of this solution was diluted to $10.0 \mu \mathrm{L}$ of Trypan blue dye and homogenized in a sterilized glass bottle and the solution was used for cell counts in Neubauer chamber. When obtained the cell concentration of $1.0 \times 10^{7}$ cells/ $\mathrm{mL}$ tubes containing the MSC were again centrifuged at $22^{\circ} \mathrm{C}$ and $1500 \mathrm{rpm}$ for 10 minutes, packed in insulated box and transported to the operating room of the Veterinary Hospital, aiming the immediate transplantation in isogenic mice C57BL/6. At the time of application the supernatant was discarded and only the pellet was used.

\section{FACS analysis}

Cells from the fourth passage were harvested with trypsin, centrifuged and resuspended at $1.0 \times 10^{6} \mathrm{cells} /$ well in phosphatebuffered saline (PBS). Cells aliquots were individual incubated with primary antibodies (anti-CD45 clone 69 mouse, anti-CD90 clone Ox-7 mouse, anti-CD73 clone 5 F/B9 mouse e anti-CD54 clone 1A29 mouse)[BD Bioscience, San Jose, CA, USA] for 30 $\min$ at $4^{\circ} \mathrm{C}$. After, the cells were washed in PBS and incubated with a fluorophore-conjugated secondary antibody (Alexa 488). The samples were analyzed using a FACScan cytometer and data were analyzed using CELLQUEST softaware (Becton Dickinson).

\section{Experiments in vivo}

The 24 animals were divided into two equal experimental groups, control group (CG) and group of association MSC/PRP (MPG). All underwent the same stress level as the manipulation and the experimental groups were conducted simultaneously.

Preceding to surgery, mice were given prophylactic antibiotic therapy with enrofloxacin $(10.0 \mathrm{mg} / \mathrm{kg}$, IM) and analgesics based on morphine $(5.0 \mathrm{mg} / \mathrm{kg}, \mathrm{SC})$, which lasted for three days and every 8 hours, targeting the pain control.

The mice were subjected to premedication with xylazine $(5.0 \mathrm{mg} / \mathrm{kg}, \mathrm{IP})$ and induction and maintenance with inhalational anesthetic, the anesthesia chamber. Then were restrained in the prone position, dorsal shaven skull, submitted to antisepsis shaved area with povidone-iodine solution and had the surgical field bordered by sterile cloth.

The skin, subcutaneous tissue and muscle were incised on the external sagittal crest of the skull from the occipital protuberance to close the eyes, approximately $1.0 \mathrm{~cm}$ in length, allowing exposure of the parietal bone. With the aid of a drill of $6.0 \mathrm{~mm}$ external diameter, connected to an electric drill at a speed of 5000rpm and under continuous irrigation with saline was performed a defect in the parietal region, with an approximate area of $28.3 \mathrm{~mm}^{2}$, reproducing the entire thickness the diploe, with exposure of the meninges, which was kept intact at the bottom of the defect.

In MPG group the defect was repaired with the pellet containing $1.0 \times 10^{7}$ cells $/ \mathrm{mL}$ and $50.0 \mu \mathrm{L}$ of plasma gel containing $1.0 \times 10^{9}$ platelets and the control group received no treatment. In both groups was placed a resorbable membrane demineralized cortical (GEN-DERM, Genius, Baumer, SP, Brazil) with a length of $0.7 \times 0.7 \mathrm{~cm}$ above the fault and beneath the skin. Subsequently, the skin was approximated with non-absorbable monofilament in separated single points. All animals were observed daily, twice daily throughout the experimental period and assessed for weight, behavior and consumption of food and water.

\section{Evaluation period}

Three animals from each group were identified, weighed and euthanized by overdosing anesthesia with thiopental sodium on days 10, 30, 60 and 90 postoperatively. Then, each mouse was restrained on the surgical table for collection of bone biopsies, involving the defect area and the adjacent portion of the receptor bone. The fragment was identified, measured, photographed and preserved in $10 \%$ buffered formaldehyde for subsequent histological processing and realization of polymerase chain reaction

\section{Morphological evaluation}

It consisted in measuring the area of the defect and establishment of the percentage of bone repair by analysis of digital photographs taken with measuring scale, light intensity and time of the digital camera steady. The digital images were transferred to a computer and analyzed by a specific program. The location and the appearance of the defect and the presence of bone growth were also recorded.

\section{Statistical analysis}

Statistical analysis was performed using specific software (System for Statistical Analysis $^{\circledR}$, v.9.1, Federal University of Viçosa, Brazil) and the Excel $^{\circledR}$ spreadsheet. The results were submitted to Kolmogorov-Smirnov test to check the distribution of the variable percentage of normal bone repair. This established the average percentage of bone repair in each study period and 
was performed independent analysis of samples by applying the Student $t$ test. To that end, we adopted a level of rejection of the null hypothesis of $5 \%(\mathrm{p} \leq 0.05)$.

\section{Microscopic evaluation}

The material was submitted to routine histologic processing, embedded in paraffin and sliced (5.0 $\mathrm{mm}$ thick) with a impact microtome with razor tungsten, involving the entire area of the defect and the edges of the receptor bone (cut lengthwise) and subsequently was stained by hematoxylin and eosin (H\&E). The samples were evaluated for the presence and characteristics of the tissue filler, using descriptive histological analysis.

\section{DNA extraction}

Genomic DNA was extracted of a culture of MSC $\mathrm{gfp}^{+}$ bone fresh animal gfp-(negative control) and a paraffin embedded samples containing the bone tissue in the defect region and cell transplantation, according to the protocol of the kit. The samples that were embedded in paraffin were deparaffinized and rehydrated prior to the steps of DNA extraction protocol, described by Nascimento et al. ${ }^{13}$.

\section{Polymerase Chain Reaction (PCR)}

PCR was carried out to the amplification of a fragment of 225 base pairs (bp) of the gfp gene using the primers: GFP-5C 5'ACT TCA AGA TCC ACA GCC ACA T 3' (direct) and GFP3C 5' TTA CTT GTA CAG CTC GTC CAT GC 3' (reverse), with the objective of verifying the presence of GFP gene in the tissue samples. The reaction was carried out in a final volume of 25.0 $\mathrm{mL}$ containing the following reagents: $7.0 \mathrm{~mL}$ of DNA sample, $2.5 \mathrm{~mL}$ of primer GFP-5C to $0.02 \mathrm{mM}, 2.5 \mathrm{~mL}$ of primer GFP-3C $0.02 \mathrm{mM}, 2.5 \mathrm{~mL}$ of the $2.0 \mathrm{mM}$ each dNTP (dATP, dTTP, dGTP, dCTP), $2.5 \mathrm{~mL}$ of Taq DNA polymerase buffer of $1 \mathrm{X}$ and $1 \mathrm{U}$ Taq DNA polymerase (QIAamp DNA Mini Kit, Uniscience, Sao Paulo, Brazil). PCR was performed with an initial denaturation step at $94^{\circ} \mathrm{C}$ for 5 minutes followed by cycles of three steps: denaturation at $94^{\circ} \mathrm{C}$ for 35 seconds, annealing at $58^{\circ} \mathrm{C}$ for 45 seconds and extension at $72^{\circ} \mathrm{C}$ for 1 minute $\mathrm{A}$ total of 40 cycles. A final extension step was performed at $72^{\circ} \mathrm{C}$ for 7 minutes. PCR products were analyzed by electrophoresis on $1.5 \%$ agarose gel and stained with ethidium bromide solution for viewing at transluminator.

\section{Results}

The culture began presenting adherent cells with morphology fibroblastoid 24 hours after plating in DMEM complete. Non-adherent cells were removed of culture by change of medium. After three days of culture $80 \%$ of confluence was observed and the first pass was realized. Intervals of three to five days were required to perform other plating and reaching the fourth passage occurred at 12 days (Figure 1). Phenotypic characterization of the MSC indicated that there was no CD45 expressions in $83.09 \%$ of the cells. There was expression of CD54 (93.83\%), CD73 (70.44\%) and CD90 (98.82\%).

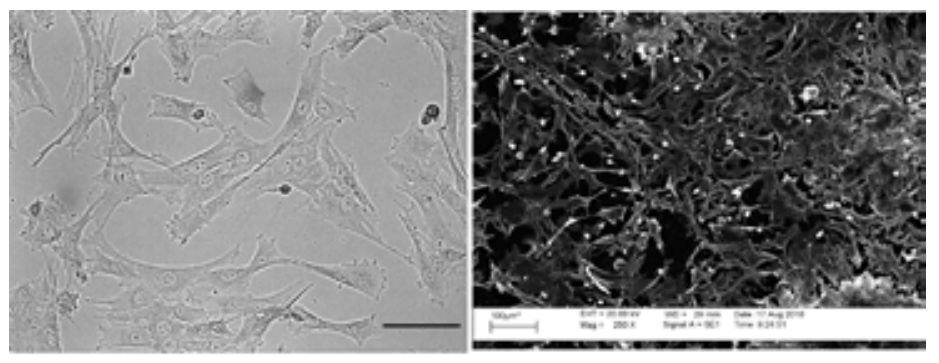

FIGURE 1 - Culture of mesenchymal stem cell in forth passage, with higher cell confluence and fibroblastoid-like cells adhered to the substrateand the culture flask. A. Photomicrograph captured of inverted optical microscope $($ escale $=50 \mu \mathrm{m})$. B. Photomicrograph captured of scanning electron microscope.

On inspection day, throughout the postoperative period, no significant weight loss, lethargy, signs of infection or neurological lesions in the animals of the study.

Macroscopic evaluation regardless of the experimental group, there was no bone growth observed around the margins and neither below the meninges. Also, we noticed the absence of total closure of defects until the final period of evaluation and adhesions between the brain, meninges, and tissue repair.

It was observed both in CG and in MPG, new bone filling the defect had thickness below the surrounding bone and receiver over the evaluation periods, the edges lost their characteristic circular perimeter, becoming irregular in places of greatest fill in.

The membrane demineralized deposited over all the defects were still present in two animals of CG, on the 10-day evaluation, and was not present in MPG. This membrane was not observed in other periods.

Even macroscopically, was observed in animals from both groups, a thin transparent tissue covering the defect, with the appearance of scar tissue above the field not repaired with bone tissue. Only two animals in the control group, an estimated 10 to 30 days and the other at this coverage was not complete. 
Through analysis of the variable percentage of bone repair were significantly different $(\mathrm{p}=0)$ between the two experimental groups at all assessment periods and that the animals MPG showed the best repair. The values of this percentage in MPG for 10 days were only observed near the GC in 60 days. Also in the MPG, the percentage of repair occurred in the initial days of the injury until the first 10 days was found higher (57\%) and declined throughout the day (11 to 30 days, $6 \%$, from 31 to 60 days, $6 \% 61$ to 90 days, $0.3 \%$ ). In CG the highest percentage was observed between days 11 and $30(30 \%)$ and the value observed at 90 days was similar to that shown at 30 days in the treated group. Table 1 shows the average percentage of bone repair exhibited by observation period for animals grouped in the control groups treated with MSC/PRP and $p$ values from the statistical study.

TABLE 1 - Mean percentage of bone repair displayed by period of observation, for animals of groups control (CG) and MSC/PRP-treated (MPG) and estimated $p$ values comparing data of $\%$ of bone filling, per period, of treatment MPG versus treatment $\mathrm{CG}$.

\begin{tabular}{ccccc} 
Treatment & $\begin{array}{c}\text { Period } \\
\text { (days) }\end{array}$ & $\begin{array}{c}\text { Areas mean } \\
\left.\mathbf{( m m}^{2}\right)\end{array}$ & $\begin{array}{c}\text { Bone } \\
\text { repair } \\
\text { percentage } \\
\left.\mathbf{( m m}^{2}\right)\end{array}$ & $\boldsymbol{p}$ value \\
\hline CG & 10 & 22.133 & 21.880 & \\
MPG & 10 & 11.926 & 57.906 & $p=0.0007$ \\
CG & 30 & 13.863 & 51.069 & \\
MPG & 30 & 10.452 & 63.179 & $p=0.0000$ \\
CG & 60 & 11.843 & 58.199 & \\
MPG & 60 & 8.767 & 69.056 & $p=0.0000$ \\
CG & 90 & 10.495 & 62.957 & \\
MPG & 90 & 8.666 & 69.413 & \\
\end{tabular}

Tests performed under light microscopy revealed that the thin transparent tissue, which covered the defects in CG and MPG, was composed of dense connective tissue with varying degrees of cellularity and contained no inflammatory cells.

In the control group at 10 days, cell proliferation was observed with slight bone formation at the edges of the defect and toward the center. The occurrence of cell infiltrate composed of basophilic cells, replacing the region previously occupied by blood clot. Most cells that participate in the repair process stemmed mainly from soft tissues (periosteum and muscles) present in the extremities of the defect.
At 30 days, in some samples, it was observed more bone formation compared to the previous period, with the new tissue by forming islands surrounded by granulation tissue and insinuating itself into the interior of defect. At this time, the blood vessels permeating the granulation tissue were present in quantities greater than those observed at 10 days.

At 60 and 90 days bone growth was progressive in relation to observation time, with the presence of bone marrow mononuclear cells interspersed with the diploe bone. Was viewed the presence of large cells, rounded, eosinophilic cytoplasm and basophilic nuclei suggestive of megakaryocytes.

In MPG, angiogenesis was higher with larger vessels than displayed on the GC. These blood vessels were concentrated mainly on the banks that receives region of formation of new bone and the amount of new vessels was greater than 10 days when compared to other periods in the same group.

At MPG was also seen in granulation tissue and an inflammatory infiltrate consisting of basophilic cells, replacing the region occupied by blood clot, similar to that observed in the CG.

At 10 days, the area of new bone formation, as observed macroscopically, was higher than found in the CG, and widened to the extent that the evaluation period progressed. Also, there was evidence of intense movement originated mobile soft tissues adjacent to the defect toward the center, and the presence of undifferentiated cell types, cuboidal morphology with round nuclei and, occupying the interior of the defect and the margins in contact with recipients. At the time of evaluation also identified early organization of the cells present inside the defect around blood vessels (Figure 2).

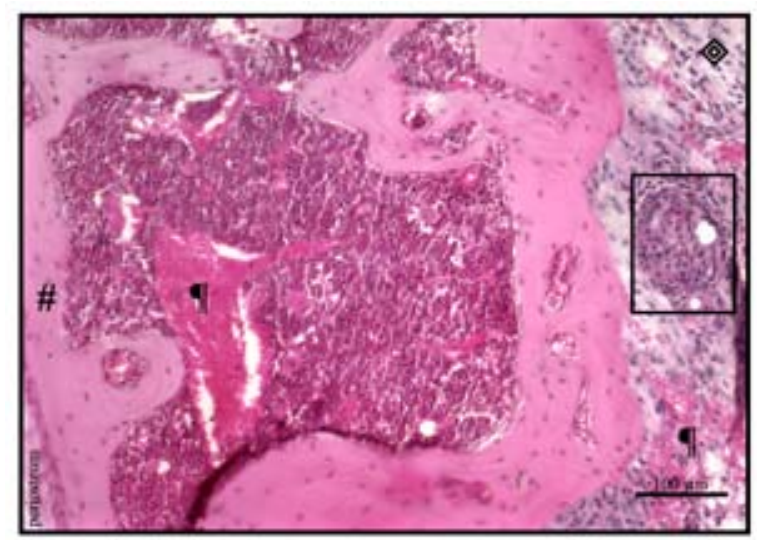

FIGURE 2 - Photomicrograph evidencing the microscopic aspect of the process of bone defect repair at 10 days in an animal from group MSC/ PRP (MPG). Presence of large numbers of undifferentiated cells inside the fault $(\diamond)$, early organization of cells present within the defect (rectangle) around a blood vessel, replacement of blood clot ( $\mathbb{( I )}$ and receptor bone (\#). (H \& E) [escale $=100 \mu \mathrm{m}]$. 
At 30 days, was observed higher new bone formation toward the center of the defect, degree of organization superior to that 10 days before the previous evaluation period. Still undifferentiated cells were visualized and fibroblastoid inside the defect, rallying from these new features, and outstanding amounts of congested blood vessels, newly formed, interspersed with new formations.

At day 60, identified himself to the larger amount of bone tissue and more organized than had hitherto been observed. In an analogous manner to that described in previous periods, there was young and undifferentiated cells near the formations of new bone. Within the newly formed blood vessels were visualized core basophilic giant cells and eosinophilic cytoplasm, suggestive of megakaryocytes. What differentiated the histological, and 90 days, was the largest organization of bone formation and osteoid tissue in osteon.

Whatever the period under review, cuboidal osteoblasts were seen queuing up at the edges of new tissue formation and increased bone matrix. In MPG, there was greater quantity of osteoblasts and osteoid tissue organization when compared to CG. Also, with advancing time, discrete foci were seen with signs of bone remodeling and presence of osteoclasts.

The sample derived from tissue that was treated with MSC / PRP showed the amplified DNA fragment of expected size and exhibited as the marking band in agarose gel 1.5\% (Figure 3). The sequencing of the PCR products is still being awaited.

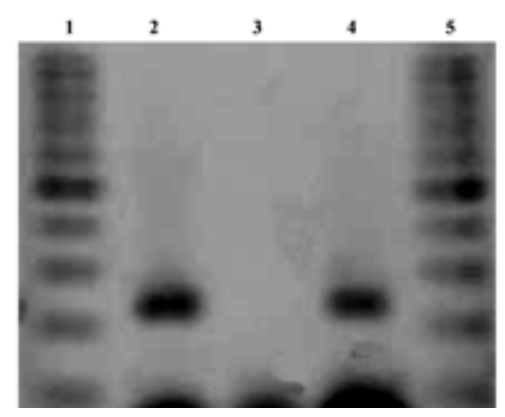

FIGURE 3 - Photography of agarose gel displaying banding of the samples submitted to PCR. Channels 1 and 5 have standard marker of 100 base pairs. Channel 2 with PCR product of cells in culture (positive control). Channel 3 with PCR product of the bone tissue sample of animal $g f p^{-}$(negative control). Channel 4 with PCR product of the paraffinized bone tissue sample of one animal treated with $\mathrm{MSC} / g f p^{+} / \mathrm{PRP}$.

\section{Discussion}

In this study, PRP, a source of autologous growth factors, was associated with mesenchymal stem cells in order to increase the proliferation and differentiation of undifferentiated cells in bone healing and getting sooner and more effective. Considering that the body's healing processes are complex and require interaction between the injured site and reparative cells, the aim is that the transplanted MSC increased the process of bone repair by release different soluble growth factors including G -CSF (colony stimulating factor granulocyte), GM-CSF (colony stimulating factor and granulocyte macrophage), M-CSF (colony stimulating factor for macrophages), TGF-beta (transforming growth factor beta) and several interleukins as described by Deans and Moseley ${ }^{8}$ and Bobis et al. ${ }^{14}$. These soluble factors are able to activate different cell types, including cells involved in inflammation, promote the differentiation of osteoprogenitor cells and induce cell activation young bone, causing bone formation earlier and in greater quantity, observed in the treated group.

Beyond all the assistance provided by the MSC, PRP is also considered a rich source of growth factors ${ }^{15}$ and stimulating agent formation of new bone. According to data presented by Ball et al. ${ }^{16}$ MSC express high levels of VEGF and PDGF receptors, which may explain, among other factors, the exuberant angiogenesis found in GMP.

The presence of PDGF (platelet derived growth factor platelet) has many positive effects on tissue repair including angiogenesis, mitogenesis of bone marrow cells and pre-osteoblasts and activation of the differentiation of mature osteoblasts that stimulate the deposition of bone matrix proteins ${ }^{15,17}$.

It was found that the MSC/PRP used as treatment of defects in the parietal portion of the skull of the mice led to increased bone formation in the control group, with trend total compensation, however, the end of the evaluation period to 90 days, the defects were not fully met. This feature shows the creation of a critical defect in the calvaria of mice $(6.0 \mathrm{~mm})$, in agreement with data available in the literature that consider critical defects with a diameter greater than $2.7 \mathrm{~mm}^{18}$. Consequently, as much as treatment with undifferentiated cells and plasma gel has increased the repair process, it was not enough to provide a complete cure.

Statistical analysis confirmed that treatment with the combination MSC / PRP increased bone repair that cause a higher amount of new bone, especially in the first 10 days after treatment, the earliest stage. Moreover, it was concluded that the highest rate of bone healing appears in the control group at 90 days was similar to the rate in the treated group at 30 days. For these data, we can infer that the release of growth factors provided by the MSC and the PRP, caused greater activation of osteoprogenitor cells, increased cell recruitment and activation of cells osteocomprometidas, with consequent increased formation of bone tissue.

The resorbable demineralized cortical membrane, used up the defects in both groups, aimed to prevent the spread of 
material deposited within the lesion once the mouse has no muscle and subcutaneous tissue in this region of the skull, in sufficient quantity to and sutured to prevent leakage of cells that were used in treatment. In the evaluation performed 30 days in both groups, it was no longer present according to data from the preliminary pilot study, conducted by the authors, who found that it does not influence the bone healing process, being completely absorbed over a period of 15 days.

In the MPG was visualized in the initial evaluation, a marked presence of inflammatory infiltrate of basophilic cells and based on previous statements ${ }^{8,14}$ we can infer that these cells may have been influenced soluble chemotactic factors released in the middle, explaining that higher counts. For Honma et al. ${ }^{19}$, the inflammatory process triggered by the surgical procedure can be initiated and maintained the differentiation of MSC into osteoblasts. Similarly, Lacey et al. ${ }^{20}$ demonstrated the potential of pro-inflammatory cytokines such as interleukin (IL-1 and IL-6) and tumor necrosis factor (TNF- $\alpha$ ), positively influencing the osteogenic potential by encouraging the production of osteoprotegerin (OPG) and receptor activator of nuclear factor $\kappa \mathrm{B}$ (RANKL), two cytokines involved in the process of deposition and resorption.

With the advance of periods of observation, as the bone formation was consolidated and activity of osteoblasts and osteoprogenitor cells decreased, there was, concomitantly, reducing of the inflammatory process. It can be inferred that the release of pro-inflammatory cytokines also dropped since it is dependent on the inflammatory process and soluble factors consumed during the repair. Also at that stage there was no need to provide so many stimuli to the osteogenic cells.

In the first evaluation period, after 10 days, was observed in the presence of MPG large amount of undifferentiated cells of fibroblastoid morphology now cuboid prays inside the defect, organizing themselves around blood vessels and initiating the formation of new bone tissue. This event was not seen in $\mathrm{CG}$ possibly because the cells observed were the MSC used in the treatment and/or undifferentiated cells attracted by soluble factors released in the middle. At 30, 60 and 90 days were also detected fibroblastoid undifferentiated cells interspersed with new bone growth, however was different from the morphology of cells observed at day 10. Possibly, after 10 days, the transplanted cells were present and at 30,60 and 90 days were the undifferentiated cells that were attracted to the repair site.

Another finding of microscopic evaluation was highlighted in an intense movement of cells from soft tissue adjacent to the center of the defect, especially in MPG, demonstrating the contribution of these cells present in the periosteum osteocomprometidas with the repair process. Shimizu et al. ${ }^{21}$ had shown that among the cells that make up the periosteum there are progenitor cells with potential to differentiate into osteoblasts, which are activated by physical or chemical stimulation, as in cases of fractures, inflammation and tumor development, and contribute to repair processes. With the same purpose, Zhang et al. ${ }^{22}$ stated that beyond the role of proliferation and differentiation into cartilage cells and bone mesenchymal progenitor cells, which are present in the periosteum, also release factors osteoinductor able to recruit and activate other cells of the host osteocompromised.

In MPG also observed greater angiogenesis and formation of new bone tissue in relation to the CG. Bone formation reflects the presence of a greater quantity of osteoblasts, which may have originated through different mechanisms of differentiation of mesenchymal precursor cells ${ }^{23,24}$ and/or have been attracted to the location of the defect by paracrine effect ${ }^{25}$. Once present at the margins of the lesion, these cells secrete osteogenic bone protein matrix, including type I collagen and proteoglycans and stimulate mineralization ${ }^{14,26}$.

The intense osteoblasts number in MPG group probably reflected the action of growth factors released by PRP recruiting bone cells committed with repair process and favored the activation and differentiation of undifferentiated cells that were transplanted, especially in the early post-operative day. Khojasteh et al. ${ }^{17}$ stressed the importance of PDGF in the recruitment of bone cells and said that although the initial PDGF secreted by platelets play an important role in the initial healing, and its subsequent secretion from macrophages recruited (present in the granulation tissue) that provides an "up-regulation" of other growth factors, angiogenesis, and recruitment and activation of cells such as fibroblasts and osteoblasts.

Regarding bone formation, the cell types present in both groups were the same. Cuboidal osteoblasts were observed, arranged in rows on the edges of new bone formation and a slight presence of osteoclasts near the new blood vessels formed. The difference between the groups was the number of cells of bone deposition was higher in the MPG. Corroborating the statements of Kasten et al. ${ }^{2}$ the addition of growth factors from plasma resulted in positive effects for larger activation and proliferation of MSC. When evaluating the contributions of reparative therapy with MSC is essential to consider the characteristics of the site where the cells are deposited. According to Fuchs et al. ${ }^{27}$ therapeutic success is dependent on the niche, in other words, the interactions of stem cells with other cells with the extracellular matrix and with 
the growth factors of environment, maintain that these quiescent cells and/or in differentiation processes. Thus, the creation of the wounds in a surgical and aseptic application of the cells in a time of acute injury process (therapeutic window) and the association with PRP acting as a source of release of other growth factors and as a platform limiting dispersion of the cells favored compliance, maintenance, differentiation and release of other soluble factors by the MSC, contributing to higher formation of bone tissue in MPG.

Cheng et al. ${ }^{28}$ conducted studies on critical defects in the skull of rabbits using PRP as the carrier vehicle of mesenchymal cells derived from bone marrow. Similarly to this study, the aforementioned authors did not find total repair of bone defects during the observation period of 12 weeks, but they concluded that the PRP gel is a promising vehicle for the application of the MSC, to provide soluble factors that contribute for osteogenesis and adequate nutrition to the cells.

The presence of band in the agarose gel detected in animals treated by the association MSC / PRP, similar to those seen in the positive control (close to $225 \mathrm{bp}$ ) confirms the presence of the reporter gene in animals treated with MSC gfp $\mathrm{gnd}^{+}$allows us to infer that the cells trunk used in the treatment remained present in the process of bone repair.

\section{Conclusion}

The association of mesenchymal stem cells (MSC) derived from bone marrow of C57BL/6 $\mathrm{gfp}^{+}$with gel autologous PRP applied in critical bone defects produced in the calvaria of C57BL/6 adult mice contributes positively to the process of bone repair.

\section{References}

1. Pieri F, Lucarelli E, Corinaldesi G, Fini M, Aldini NN, Giardino R, Donati D, Marchetti C. Effect of mesenchymal stem cells and platelet-rich plasma on the healing of standardized bone defects in the alveolar ridge: a comparative histomorphometric study in minipigs. J Oral Maxillofac Surg. 2009;67(2):265-72.

2. Kasten P, Vogel J, Beyen I, Weiss S, Niemeyer P, Leo A, Lüginbuhl R. Effect of platelet-rich plasma on the in vitro proliferation and osteogênico differentiation of human mesenchymal stem cells on distinct calcium phosphate scaffolds: the specific surface area makes a difference. J Biomater Appl. 2008;23(2):169-88.

3. Meirelles LS, Caplan AI, Nardi NB. In search of the in vivo identity of mesenchymal stem cells. Stem Cells. 2008;26(9):2287-99.

4. Caplan AI. Why are MSCs therapeutic? New data: new insight. J Pathol. 2009;217(2):318-24.

5. Caplan AI. Mesenchymal stem cells. J Orthop Res. 1991;9(5):64150 .

6. Pittenger MF, Mackay AM, Beck SC, Jaiswal RK, Douglas R, Mosca JD, Moorman MA, Simonetti DW, Craig S, Marshak DR.
Multilineage potential of adult human mesenchymal stem cells. Science. 1999;284(5411):143-7.

7. Nardi NB, Meirelles LS. Mesenchymal stem cells: Isolation, in vitro expansion and characterization. Handb Exp Pharmacol. 2006; 174:249-82.

8. Deans RJ, Moseley AB. Mesenchymal stem cells: biology and potencial clinical uses. Exp Hematol. 2000;28(8):875-84.

9. Muraki K, Hirose M, Kotobuki N, Kato Y, Machida H, Takakura Y, Ohgushi H. Assessment of viability and osteogenic ability of human mesenchymal stem cells after being stored in suspension for clinical transplantation. Tissue Eng. 2006;12(6):1711-9.

10. Marx RE, Carlson ER, Eichstaedt RM, Schimmele SR, Strauss JE, Georgeff KR. Platelet-rich plasma. Growth factor enhancemente for bone grafts. Oral Surg Oral Med Oral Pathol Oral Radiol Endod. 1998;85(6):638-46.

11. Silva PSA, Del Carlo RJ, Serakides R, Monteiro BS, Balbinot PZ, Eleotério RB, Paez OLA, Viloria MIV. Plasma rico em plaquetas (PRP) associado ou não ao osso esponjoso autógeno no reparo de falhas ósseas experimentais. Ciênc Rural. 2009;39(1):129-34.

12. van den Dolder J, Mooren R, Vloon APG, Stoelinga PJ, Jansen JA. Platelet-Rich Plasma: quantification of growth factor levels and the effect on growth and differentiation of rat bone marrow cells. Tissue Eng. 2006;12(11):3067-73.

13. Nascimento EM, Spinelli MO, Rodrigues CJ, Bozzini N. Protocolo da extração de DNA de material parafinado para análise de microssatélites em leiomioma. J Bras Patol Med Lab. 2003;39(3):253-5.

14. Bobis S, Jarocha D, Majka M. Mesenchymal stem cells: characteristics and clinical applications. Folia Histochem Cytobiol. 2006;44(4):215-30.

15. Marx RE. Platelet-Rich Plasma: evidence to support its use. J Oral Maxillofac Surg. 2004;62:489-96.

16. Ball SG, Shuttleworth CA, Klelty CM. Mesenchymal stem cells and neovascularization: role of platelet-derived growth factor receptors. J Cell Mol Med. 2007;11(5):1012-30.

17. Khojasteh A, Eslaminejad MB, Nazarian H. Mesenchymal stem cells enhance bone regeneration in rat calvarial critical size defects more than platelet-rich plasma. Oral Surg Oral Med Oral Pathol Oral Radiol Endod. 2007;106:356-62.

18. Seo BM, Sonoyama W, Yamaza T, Coppe C, Kikuiri T, Akiyama K, Lee JS, Shi S. SHED repair critical-size calvarial defects in mice. Oral Dis. 2008;14(5):428-34

19. Honma T, Itagaki T, Nakamura M. Kamakura S, Takahashi I, Echigo S, Sasano Y. Bone formation in rat calvaria ceases within a limited period regardless of completion of defect repair. Oral Dis. 2008;14(5):457-64.

20. Lacey DC, Simmons PJ, Graves SE, Hamilton, JA. Proinflammatory cytokines inhibit osteogenic differentiation from stem cells: implications for bone repair during inflammation. Osteoarthritis Cartilage. 2009;17(6):735-42.

21. Shimizu T, Sasano Y, Nakajo S, Kagayama M, Shimauchi H. Osteoblastic differentiation of periosteum-derived cells is promoted by physical contact with the bone matrix in vivo. Anat Rec. 2001;264(1):72-81.

22. Zhang X, Xie C, Lin AS, Ito H, Awad H, Lieberman JR, Rubery PT, Schwarz EM, O'Keefe RJ, Guldberg RE. Periosteal progenitor cell fate in segmental cortical bone graft transplantations: implications for functional tissue engineering. J Bone Miner Res. 2005;20(12):212437.

23. Herzog EL, Chai L, Krause DS. Plasticity of marrow-derived stem cells. Blood. 2003;102:3483-93.

24. Meirelles LS, Chagastelles PC, Nardi NB. Mesenchymal stem cells reside in virtually all post-natal organs and tissues. J Cell Sci. 
2006;119(11):2204-13.

25. Moore BE, Quesenberry PJ. The adult hemopoietic stem cell plasticity debate: idols vs new paradigms. Leukemia. 2003;17:120510.

26. Shen F, Ruddy MJ, Plamondon P, Gaffen SL. Cytokines link osteoblasts and inflammation: microarray analysis of interleukin-17 and TNF- $\alpha$ induced genes in bone cells. J Leukoc Biol. 2005;77(3):388-99.

27. Fuchs E, Tumbar T, Guasch G. Socializing with the neighbours: stem cells and their niche. Cell. 2004;116(6):769-78.

28. Cheng X, Lei D, Mao T, Yang S, Chen F, Wu W. Repair of critical defects with injectable platelet-rich plasma/bone marrow-derived stromal cells composite: experimental study in rabbits. Ulus Travma Acil Cerrahi Derg. 2008;14(2):87-95.

\section{Acknowledgements}

The authors thank for the researches of the Laboratory of Immunogenetics, Federal University of Rio Grande do Sul, Laboratory of Biochemistry and Molecular Biology of Infectious and Parasitic, Laboratory of Biology and Control Hematozoa Vectors and the Federal University of Viçosa for technical supportt.

\section{Correspondence:}

Betânia Souza Monteiro

Centro Universitário Vila Velha

Departamento de Veterinária - Hospital Veterinário

Rua Comissário José Dantas de Melo, 21

29102-770 Vila Velha - ES Brasil

betania.monteiro@uvv.br

Received: October 18, 2011

Review: December 14, 2011

Accepted: January 20, 2012

Conflict of interest: none

Financial sources: FAPEMIG, CAPES, CNPq

${ }^{1}$ Research performed at Department of Veterinary, Federal University of Viçosa (UFV), Brazil. Part of PhD thesis of Betania Souza Monteiro. 